ISSN 2252-9063

Kumpulan Artikel Mahasiswa Pendidikan Teknik Informatika

(KARMAPATI)

Volume 8 Nomor 2 Tahun 2019

\title{
PENGARUH KELAS MAYA BERBASIS PROYEK TERHADAP HASIL BELAJAR SIMULASI DAN KOMUNIKASI DIGITAL KELAS X PERHOTELAN SMK PGRI 3 BADUNG
}

\author{
Ketut Widi Sastra ${ }^{1}$, Ketut Agustini ${ }^{2}$, I Gede Partha Sindu, ${ }^{3}$, Program Studi Pendidikan Teknik Informatika \\ Program Studi Pendidikan tTeknik Informatika \\ Jurusan Teknik Informatika \\ Fakultas Teknik dan Kejuruan \\ Universitas Pendidikan Ganesha \\ Singaraja, Bali \\ E-mail:widisastra1995@gmail.com, ketutagustini@undiksha.ac.id.Partha.sindu@undiksha.ac.id
}

\begin{abstract}
Abstrak Penelitian bertujuan untuk mengetahui (1) pengaruh kelas maya berbasis Proyek pada mata pelajaran Simulasi dan Komunikasi Digital terhadap hasil belajar siswa kelas X Perhotelan SMK PGRI 3 Badung (2) Untuk mengetahui respon siswa terhadap penerapan kelas maya berbasis proyek mata pelajaran Simulasi dan Komunikasi Digital. Jenis penelitian ini adalah eksperimen semu (quasi eksperimen) dengan desain Post Test Only Control Group Design. Populasi penelitian mencakup seluruh siswa kelas X Perhotelan SMK PGRI 3 Badung Tahun Pelajaran 2018/2019. Sampel yang digunakan yaitu kelas X AP 1 yang digunakan sebagai kelas eksperimen dan X AP 2 yang digunakan sebagai kelas kontrol, dengan jumlah 90 orang. Metode pengumpulan data yang digunakan yaitu dengan metode tes pilihan essay untuk mengatur ranah kognitif kemudian dianalisis dengan meliputi uji normalitas, uji homogenitas dan uji hipotesis dan metode kuisioner untuk melihat respon siswa. Manfaat hasil penelitian ini dapat meningkatkan hasil belajar pengetahuan siswa terhadap mata pelajaran Simulasi dan Komunikasi Digital serta respon siswa dengan media pembelajaran kelas maya .
\end{abstract}

Kata-kata kunci : Simulasi dan Komunikasi Digital, Respon siswa, Post Test Only Control Group Design.

\section{ABSTRACT}

The study aims to determine (1) the effect of Projectbased virtual classes on Digital Simulation and Communication subjects on the learning outcomes of class X Hospitality students of SMK PGRI 3 Badung (2) to determine students' responses to the application of

project-based virtual classes to Simulation and Digital Communication subjects. This type of research is a quasiexperimental (quasi-experimental) design with Post Test Only Control Group Design. The population of the study included all students of class X Hospitality in SMK PGRI 3 Badung Academic Year 2018/2019. The sample used was class X AP 1 which was used as the experimental class and X AP 2 which was used as the control class, with 92 people. The method of data collection used is a multiple choice test method to regulate the cognitive domain then analyzed by including the normality test, homogeneity test and hypothesis test and questionnaire method to see student responses. The benefits of the results of this study can improve the learning outcomes of students 'knowledge of Digital Simulation and Communication subjects and students' responses to virtual classroom learning media.

key words: virtual classroom learning, Digital Simulation and Communication, Student response 


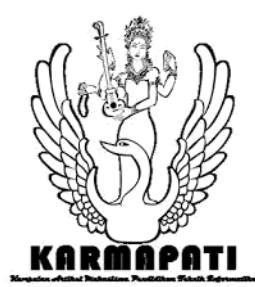

ISSN 2252-9063

Kumpulan Artikel Mahasiswa Pendidikan Teknik Informatika

(KARMAPATI)

Volume 8 Nomor 2 Tahun 2019

\section{LATAR BELAKANG}

Peran pendidikan sangatlah penting, terutama untuk meningkatkan kualitas sumber daya manusia. Pendidikan harus mampu mencetak individu-individu yang mempunyai pengetahuan tinggi, daya kompetitif, kreativitas, dan sikap budi pekerti agar kualitas sumber daya manusia semakin meningkat. Hal ini sesuai dengan tujuan pendidikan yang tercantum dalam undang-undang. Amaliah (2012: 1) mengutip Undang-Undang No. 20 tahun 2003 tentang Sisdiknas disebutkan bahwa: "Pendidikan nasional berupaya untuk mengembangkan kemampuan dan membentuk watak serta peradaban bangsa yang bermartabat dalam rangka mencerdaskan kehidupan bangsa, bertujuan untuk mengembangkan potensi agar menjadi manusia yang beriman dan bertakwa kepada Tuhan Yang Maha Esa, berakhlak mulia, sehat, berilmu, cakap, kreatif, mandiri, dan menjadi warga negara yang demokratis serta bertanggung jawab". Sehingga jika kualitas pendidikan rendah, maka tujuan pendidikan tidak akan tercapai dan mengakibatkan rendahnya penyediaan sumber daya manusia yang berkualitas, berdasarkan kriteria siswa dalam pembelajaran.

Hasil penyebaran angket yang dilakukan di kelas $\mathrm{X}$ Perhotelan SMK PGRI 3 Badung(angket observasi siswa terdapat pada lampiran 3)menyatakan bahwa selama ini sumber belajar pada pelajaran simulasi dan komunikasi digital siswa kelas $\mathrm{X}$ Perhotelan masih bersumber pada buku/modul, internet dan penjelasan guru $(11,67 \%$ mengatakan bersumber dari modul, $30 \%$ mengatakan bersumber dari internet dan 58,33 \% mengatakan bersumber dari penjelasan guru). Siswa lebih tertarik menggunakan media elektronik sebagai media pembelajaran $(78,89 \%$ mengatakan siwa tertarik pada media elektronik) karena media elektronik mudah digunakan.Dilihat dari nilai siswa masih terdapat beberapa siswa yang mengatakan bahwa nilai mereka tidak memuaskan disebabkan karena siswa kurang mengerti pada pelajaran ini $(67,22 \%$ mengatakan hasil belajar siswa kurang memuaskan). Hal tersebut dapat dilihat dari nilai Ulangan Akhir Semester (UAS) yang dicapai siswa kelas $\mathrm{X}$ Perhotelan semester ganjil pada mata pelajaran Simulasi dan Komunikasi Digital tahun pelajaran 2017/2018 yang dapat dilihat pada Tabel 1

Tabel 1. Nilai Rata-rata UAS Siswa Kelas X Perhotelan Semester Ganjil Pada Mata Pelajaran Simulasi dan Komunikasi Digital Tahun Pelajaran 2017/2018

\begin{tabular}{|c|c|c|c|}
\hline KKM & Tahun & Tuntas & $\begin{array}{c}\text { Tidak } \\
\text { Tuntas }\end{array}$ \\
\hline 75 & $2017 / 2018$ & $32,78 \%$ & $67,22 \%$ \\
\hline
\end{tabular}

Tabel 1 Nilai UAS Semester Ganjil
Sumber: Daftar Nilai UAS Semester Ganjil Guru Simulasi dan Komunikasi Digital Kelas X Perhotelan SMK PGRI 3 Badung

Berdasaran Tabel 1. terlihat bahwa tingkat perolehan nilai siswa yang mencapai KKM sebanyak $32,78 \%$ dan siswa yang nilainya tidak mencapai KKM sebanyak $67,22 \%$ dari jumlah keseluruhan siswa kelas X Perhotelan yaitu 187 orang. Hal ini menandakan bahwa hasil belajar siswa pada mata pelajaran Simulasi dan Komunikasi Digital masih banyak yang belum mencapai KKM sehingga memerlukan perhatian semua pihak.

Berdasarkan hasil observasi peneliti di sekolah SMK PGRI 3 Badung dengan salah satu guru mata pelajaran Simulasi dan Komunikasi Digital menyatakan bahwa siswa sering tidak fokus dalam pembelajaran dan sering bingung dalam memahami materi pelajaran ini dikarenakan kurangnya bahan ajar yang digunakan dalam proses pembelajaran, sehingga siswa merasa bosan dan cendrung hanya sekadar melihat dan mendengarkan penjelasan dari guru, siswa cenderung malas untuk mempelajari kembali materi-materi sebelumnya, dan saat pertemuan selanjutnya siswa sering lupa tentang materi yang sudah diberikan. Selama ini pula guru masih mengguanakan media power point sebagai alat bantu dalam pembelajaran Simulasi dan Komunikasi Digital sehingga kesan monoton yang dapat menyebabkan siswa merasa bosan. Hal ini akan berdampak pada KKM siswa kelas X SMK PGRI 3 Badung yang pada tahun ajaran 2017/2018 mulai mengalami penurunan.

Menurut Sabda berbagai model pembelajaran yang memadukan teknologi berbasis web pun mulai dikembangkan seperti pembelajaran dengan e-learning, e-modul ataupun blended learning. Salah satu penggunakan media pembelajaran alternativeadalah penggunaan e-learning.E-learning adalah sitem atau konsep pendidikan yang memanfaatkan teknologi informasi dalam proses belajar mengajar. Proses pembelajaran eleraningdapat memfasilitasi keterlibatan peserta didik melalui pengetahuan yangdidapat dalam proses pembelajaran, meningkatkan interaksi diantara peserta didiksecara bermakna, mempermudah akses terhadap informasi, membantuperkembangan kreativitas dan komunikasi yang dibutuhkan peserta didik agarlebih terlibat dalam proses pembelajaran ${ }^{[1]}$.

Berdasarkan penelitian yang sebelumnya yang dilakukan terkait dengan penelitian media pembelajaran e-learning kelas maya, didapatkan beberapa hasil penelitian yang relavan dengan media pembelajaran e-learning kelas maya, yaitu menyatakan bahwa E-learning yang digunakan sebagai suplemen adalah e-learning yang berasal dari situs e-learning Kemdikbud yakni Rumah Belajar yang dipantau menggunakan group diskusi facebook untuk mengontrol pembelajaran siswadengan metode kuasi eksperimen yang menggunakan 


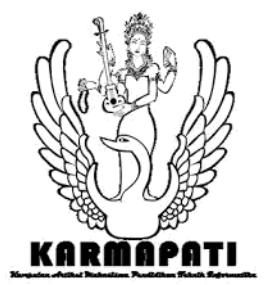

ISSN 2252-9063

Kumpulan Artikel Mahasiswa Pendidikan Teknik Informatika

(KARMAPATI)

Volume 8 Nomor 2 Tahun 2019

desain pretest-posttest control group design. Analisis data posttest diperoleh thitung sebesar 8,26 dan ttabel pada taraf signifikan 5\% yaitu sebesar 1,99 maka thitung>ttabel. Hal tersebut menunjukkan bahwa terdapat pengaruh pembelajaran direct instruction dengan suplemen rumah belajar (situs elearning kemdikbud) terhadap hasil belajar pada materi sistem saraf manusia ${ }^{[2]}$.

\section{A. Teori Belajar}

\section{KAJIAN TEORI}

Belajar merupakan suatu proses perubahan perilaku atau pribadi atau perubahan struktur kognitif seseorang berdasarkan praktk atau pengalaman tertetu hasil interaksi aktifnya dengan lingkungan dan sumber-sumber pembelajaran yang ada disekitarnya.

1. Teori Belajar Behavioristik

Teori belajar behavioristic merupakan teori dengan pandangan tentang belajar sebagai periubahan dalam tingkah laku sebagai akibat dari interaksi antara stimulus (rangsangan) dan respon (perilaku reaktif).

2. Teori Belajar Kognitivisme

teori belajar kognitivisme adalah rasional. Pengetahuan seseorang diperoleh berdasarkan pemikiran. Inilah yang disebut dengan filosofi rasionalisme.Teori belajar kognitif lebih mementingkan proses belajar dari pada hasil belajarnya $^{[3]}$.

3. Teori Belajar Konstruktivisme

belajar merupakan suatu proses pembentukan pengetahuan. Pembentukan ini harus dilakukan oleh si belajar. Ia harus aktif melakukan kegiatan, aktif berpikir, menyusun konsep dan memberi makna tentang hal-hal yang sedang dipelajari.

4. Teori Belajar Connectionism

Teori belajar connectivism merupaka teori pembelajaran yang digunakan untuk era digital masa kini dan merupakan alternative teori pembelajaran pada abad digital. ${ }^{[4]}$.

\section{B. Model Pembelajaran Project Based Learning}

Pembelajaran Berbasis Proyek (Project Based Learning = PjBL) adalah metode pembelajaran yang menggunakan proyek/kegiatan sebagai media. Peserta didik melakukan eksplorasi, penilaian, interpretasi, sintesis, dan informasi untuk menghasilkan berbagai bentuk hasil belajar. Pembelajaran Berbasis Proyek merupakan metode belajar yang menggunakan masalah sebagai langkah awal dalam mengumpulkan dan mengintegrasikan pengetahuan baru berdasarkan pengalamannya dalam beraktifitas secara nyata ${ }^{[5]}$.

\section{Kelebihan dan Kekurangan Model Pembelajaran Berbasis Proyek}

beberapa keuntungan dan kelemahan dari pembelajaran berbasis proyek antara lain sebagai berikut.

\section{Keuntungan :}

a. Meningkatkan motivasi belajar peserta didik untuk belajar, mendorong kemampuan mereka untuk melakukan pekerjaan penting, dan mereka perlu untuk dihargai.

b. Meningkatkan kemampuan pemecahan masalah.

\section{Kelemahan:}

a. Memerlukan banyak waktu untuk menyelesaikan masalah.

b. Membutuhkan biaya yang cukup banyak.

c. Banyak peralatan yang harus disediakan.

\section{E-Learning}

E-learning merupakan pembelajaran jarak jauh yang menggunakan teknologi komputer atau biasanya disebut internet. Henderson dalam menjelaskan e-learning merupakan pembelajaran berbasis web yang bisa diakses dari internet. mendefinisikan e-learning sebagai sembarang pembelajaran menggunakan rangkaian elektronik (Local Area Network (LAN), Wide Area Network (WAN), atau internet) untuk menyampaikan isi pembelajaran, interaksi atau bimbingan. ${ }^{[6]}$.

mengemukakan proses pembelajaran eleraning dapat memfasilitasi keterlibatan peserta didik melalui pengetahuan yang didapat dalam proses pembelajaran, meningkatkan interaksi diantara peserta didik secara bermakna, mempermudah akses terhadap informasi, membantu perkembangan kreativitas dan komunikasi yang dibutuhkan peserta didik agar lebih terlibat dalam proses pembelajaran ${ }^{[7]}$.

\section{Kelas maya Rumah Belajar}

Pustekkom Kemdikbud telah membuat dan mengembangkan Rumah Belajar sejak tahun 2011 sebagai salah satu portal pembelajaran berbasis web, yang berisi berbagai layanan pembelajaran seperti Kelas Maya, Lab Maya, Sumber Belajar, dan Peta Budaya. Rumah Belajar merupakan portal pembelajaran resmi miliki Kementerian Pendidikan dan Kebudayaan yang bisa diakses dengan alamat URL http://belajar.kemdikbud.go.id.

\section{E. Mata Pelajaran Simulasi Dan Komunikasi Digital}

Komunikasi telah digunakan sejak manusia pertama diturunkan ke muka bumi. Para ahli memaknai komunikasi antara lain sebagai berikut. Komunikasi adalah proses penyampaian pikiran atau perasaan oleh seseorang kepada orang lain dengan menggunakan lambang-lambang yang bermakna bagi kedua pihak, dalam situasi yang tertentu komunikasi menggunakan media tertentu

\section{F. Hasil Belajar}

Hasil belajar merupakan bagian terpenting dalam pembelajaran. mendefinisikan hasil belajar siswa pada hakikatnya adalah perubahan tingkah laku sebagai hasil belajar dalam pengertian yang lebih luas mencakup bidang kognitif, afektif, dan psikomotorik.juga menyebutkan hasil belajar 


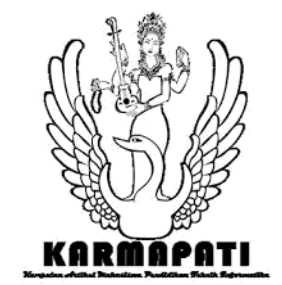

merupakan hasil dari suatu interaksi tindak belajar dan tindak mengajar. Dari sisi guru, tindak mengajar diakhiri dengan proses evaluasi hasil belajar ${ }^{[8]}$.

Berdasarkan pengertian hasil belajar di atas, disimpulkan bahwa hasil belajar adalah kemampuan-kemampuan yang dimiliki siswa setelah menerima pengalaman belajarnya. Kemampuan-kemampuan tersebut mencakup aspek kognitif, afektif, dan psikomotorik. Hasil belajar dapat dilihat melalui kegiatan evaluasi yang bertujuan untuk mendapatkan data pembuktian yang akan menunjukkan tingkat kemampuan siswa dalam mencapai tujuan pembelajaran.

\section{G. Kerangka Berfikir}

Langkah pertama dalam penelitian ini adalah melaksanakan observasi lapangan di SMK PGRI 3 Badungyang dilakukan pada tanggal 15 Januari 2019.Pada Observasi dilapangan ditemukan beberapa kendala atau masalah pada proses pembelajaran siswa yaitu diperoleh data bahwa saat proses belajar mengajar media yang diterapkan hanya bersumber dari penjelasan guru dan sisanya dari modul berupa LKS dan internet. Kendala yang terjadi yaitu masalah waktu dan juga buku tentang materi yang belum memadai dan terstruktur sehingga berakibat pada kejenuhan siswa untuk memahami materi pembelajaran. Meskipun ketertarikan siswa untuk belajar Simulasi dan Komunikasi Digital sangat tinggi namun mereka berharap saat proses pembelajaran tidak sepenuhnya bersumber dari penjelasan guru.

Guru merupakan salah satu unsur manusia dalam proses belajar, dimana peran seorang guru sangatlah penting dalam merealisasikan pendidikan yang berkualitas. Dalam menghasilkan kegiatan pembelajaran yang berkualitas, guru perlu memperhatikan beberapa aspek yaitu kegiatan pembelajaran, penggunaan model dan media pembelajaran yang menarik dan bervariasi dalam menunjang kegiatan pembelajaran, dan perilaku belajar peserta didik.

Solusi dari masalah yang ditemukan pada saat observasi lapangan adalah penggunaan media pembelajaran berupa $e$ learning yang salah satunya adalah menggunakan e-learning kelas maya.

\section{H. Hipotesis Penelitian}

Hipotesis adalah jawaban sementara terhadap masalah penelitian, yang kebenarannya masih perlu diuji secara empiris (Sugiyono, 2012). Dilakukan penelitian lebih lanjut untuk membuktikan apakah hipotesis tersebut benar adanya atau tidak benar.

Berdasarkan rumusan masalah dan kerangka berfikir, maka hipotesis penelitian dirumuskan sebagai berikut:

1. Terdapat hasil belajar yang lebih tinggi antara siswa yang belajar menggunakan e-learningkelas maya dengan siswa yang belajar tanpa menggunakan $e$ -
ISSN 2252-9063

Kumpulan Artikel Mahasiswa Pendidikan Teknik Informatika

(KARMAPATI)

Volume 8 Nomor 2 Tahun 2019

learning pada kelas X Perhotelan SMK PGRI 3 Badung.

2. Terdapat respon yang positif dari siswa kelas $X$ Perhotelan SMK PGRI 3 Badung dalam proses pembelajaran setelah menggunakan e-learning pada mata pelajaran Simulasi dan Komunikasi Digital.

\section{METODOLOGI}

Pada penelitian ini diberikan perlakuan yang berbeda antara ke dua kelas sampel yang digunakan. Kelas pertama sebagai kelas ekperimen akan diberikan perlakuan berupa penambahan penggunaan media pembelajaran berupa $e$ learning kelas maya dalam mata pelajaran Simulasi dan Komunikasi Digital, sedangkan kelas kedua sebagai kelas control akan diberikan perlakuan berupa penggunaan bahan ajar konvensional dalam mata pelajaran yang sama yaitu pada pelajaran Simulasi dan Komunikasi Digital.

Penelitian ini dilaksanakan di SMK PGRI 3 Badung kelas X Jurusan Perhotelan. Waktu pelaksanaan penelitian ini adalah semester genap pada tahun ajaran 2018/2019

Pelaksanaan penelitian tidak akan berhasil jika tidak terdapat subjek penelitian yaitu adanya sampel penelitian, dalam hal ini subjek penelitian diambil pada lokasi penelitian yaitu di SMK PGRI 3 Badung. Untuk menentukan sampel penelitian ini maka sebelumnya akan diperlukan keberadaan populasi.

Rancangan penelitian yang digunakan adalah rancangan penelitian eksperimental semu (quasi) dengan pola dasar Post Test Only Control Group Design. Dalam rancangan ini pengambilan sampel dilakukan dengan memilih kelas yang akan dijadikan sampel secara random.

Tujuan penelitian ini adalah ingin mengetahui hasil belajar siswa kelas X Jurusan Perhotelan pada mata pelajaran Simulasi dan Komunikasi Digital. Pengumpulan data dalam penelitian ini menggunakan metode tes. Tes hasil belajar yang dikembangkan disesuaikan dengan jenjang kemampuan kognitif. Tes sebagai alat bantu mengukur berisikan serangkaian pertanyaan atau tugas yang harus dijawab, dikerjakan, atau dilaksanakan oleh responden yang hendak dites.

Hasil penilaian pakar terhadap validitas isi umumnya bersifat kualitatif. Salah satu teknik pengujian validitas isi yang lebih kuantitatif yaitu Formula Greogory.

1. Validitas Isi $=\frac{D}{A+B+C+D}$

Keterangan:

A $\quad=$ sel yang menunjukkan ketidaksetujuan antara kedua penilai

$\mathrm{B}$ dan $\mathrm{C}=$ sel yang menunjukkan perbedaan pandangan antara penilai

D $\quad=$ sel yang menunjukkan persetujuan yang valid 


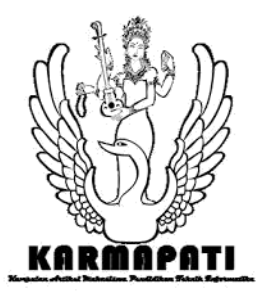

$Y_{p b i}=\frac{M_{p}-M_{i}}{S_{t}} \sqrt{\frac{p}{q}}$

Keterangan :

$Y_{p b i}=$ validitas butir soal

$\mathrm{M}_{\mathrm{p}} \quad$ = Rerata Skor dari subyek yang menjawab betul butir yang dicari validitasnya.

$\mathrm{M}_{\mathrm{t}} \quad=$ Rerata skor total

$\mathrm{S}_{\mathrm{t}} \quad=$ Standar deviasi skor total

$\mathrm{p} \quad$ = Proporsi siswa yang menjawab benar butir yang dicari validitasnya

$\mathrm{q}=$ Proporsi siswa yang menjawab salah butir yang dicari validitasnya $\mathrm{q}=1-\mathrm{p}$ )

2. Butir soal yang dinyatakan valid akan digunakan dalam Posttest sedangkan butir soal yang tidak valid akan dibuang apabila butir soal yang valid sudah mencukupi untuk Posttest.

$r_{11}=1-\left(\frac{S_{d}^{2}}{S_{t}^{2}}\right)$

Keterangan:

$\mathrm{r}_{11} \quad=$ reliabilitas tes

$S_{d}^{2}=$ varian perbedaan skor belahan pertama dan kedua

$S_{t}^{2} \quad=$ varian total

$r_{11}=\left(\frac{n}{n-1}\right)\left(\frac{S_{t}^{2}-n \overline{p q}}{S_{t}^{2}}\right)$

Keterangan :

$\mathrm{r}_{11} \quad=$ Reliabilitas soal

$\mathrm{S}_{\mathrm{t}} \quad=$ Standar deviasi skor total

$\mathrm{n} \quad=$ Banyak butir

$\bar{p} \quad=$ Proporsi rata-rata siswa yang menjawab benar untuk

semua butir

$\bar{q} \quad=$ Proporsi rata-rata siswa yang menjawab salah untuk semua butir

$r_{11}=\left(\frac{n}{n-1}\right)\left(\frac{S_{t}^{2}-\Sigma \overline{p q}}{s_{t}^{2}}\right)$

$\mathrm{r}_{11} \quad=$ Reliabilitas soal

$\mathrm{n} \quad=$ Banyak butir

$\mathrm{S}_{\mathrm{t}} \quad=$ Standar deviasi skor total

$\mathrm{p} \quad=$ Proporsi rata-rata siswa yang menjawab benar untuk tiap-tiap butir

$\mathrm{q}=$ = Proporsi rata-rata siswa yang menjawab salah untuk tiap-tiap butir

3. Rumus IKB

$I=\frac{B}{J S}$
ISSN 2252-9063

Kumpulan Artikel Mahasiswa Pendidikan Teknik Informatika

(KARMAPATI)

Volume 8 Nomor 2 Tahun 2019

Keterangan:

I = Indeks Kesukaran butir

B = Banyaknya siswa yang menjawab butir dengan benar

JS = Jumlah siswa yang mengikuti tes

4. Adapun Pembagiantingkat kesukaran menurut Witherington adalah sebagai berikut :

a. Butir dengan $\mathrm{P} 0,00$ sampai 0,24 tergolong sukar

b. Butir dengan $\mathrm{P} 0,25$ sampai 0,74 tergolong sedang

c. Butir dengan $\mathrm{P} 0,75$ sampai 1,00 tergolong mudah

$\mathrm{DB}=\frac{B a}{J a}-\frac{B b}{j b}$

Keterangan:

DB : Indeks daya beda tes

$\mathrm{Ba}$ : banyak kelompok atas yang menjawab butir dengan benar

Ja : banyak peserta kelompok atas

$\mathrm{Bb}$ : banyak kelompok bawah yang menjawab butir dengan benar

$\mathrm{Jb} \quad$ : banyak peserta kelompok bawah

\section{Teknik Analisis Deskriptif}

Data skor posttest kemudian dikategorikan sesuai dengan pedoman pada Tabel 1 berikut.

Rumus yang digunakan untuk menghitung rata-rata, varians

\begin{tabular}{|l|l|}
\hline Rentangan Skor & Kategori \\
\hline $\mathrm{MI}+1,5 \mathrm{SDI} \leq \bar{X}$ & Sangat Tinggi \\
\hline $\begin{array}{l}\mathrm{MI}+0,5 \mathrm{SDI} \leq \bar{X}<\mathrm{MI}+1,5 \\
\text { SDI }\end{array}$ & Tinggi \\
\hline $\begin{array}{l}\text { MI }-0,5 \text { SDI } \leq \bar{X}<\mathrm{MI}+0,5 \\
\text { SDI }\end{array}$ & Sedang \\
\hline $\begin{array}{l}\text { MI }-1,5 \text { SDI } \leq \bar{X}<\mathrm{MI}-0,5 \\
\text { SDI }\end{array}$ & Rendah \\
\hline $\bar{X}<\mathrm{MI}-1,5$ SDI & Sangat Rendah \\
\hline
\end{tabular}

dan standar deviasi adalah sebagai berikut.

A. Rata-Rata

$$
\mathrm{M}=\left(\frac{\sum x}{n}\right)
$$

Keterangan :

$\begin{array}{ll}\mathrm{M} & =\text { Skor rata-rata } \\ \sum_{\mathrm{n}} \mathrm{x} & =\text { Jumlah skor total } \\ & =\text { Jumlah data }\end{array}$

B. Varians

$$
s^{2}=\frac{\sum F i(X i-X)^{2}}{n-1}
$$




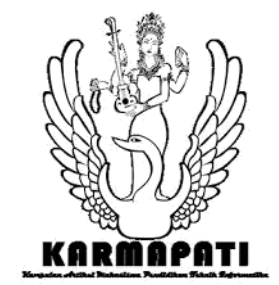

$\mathrm{Xi}=$ tanda kelas interval

$\mathrm{Fi}$ = frekuensi yang sesuai dengan $\mathrm{Xi}$

$\mathrm{X} \quad=$ mean

$\mathrm{N}$ = banyak siswa

C.Standar Deviasi

$$
\mathbf{S}=\sqrt{\mathbf{S}^{2}}
$$

Keterangan :

$\mathrm{S}$
$\mathrm{s}^{2}$

\section{Teknik Uji Prasyarat Analisis}

Data hasil penelitian dianalisis dengan uji-t. Syarat yang harus dipenuhi dalam uji-t meliputi (1) data berdistribusi normal dan (2) varians dalam kelompok homogeny. Sebelum dianalisis, terlebih dahulu dilakukan uji prasyarat. Uji prasyarat ini dilakukan untuk membuktikan bahwa data yang dikumpulkan layak untuk dianalisis dengan statistik parametrik atau tidak. Terkait dengan statistik yang digunakan untuk analisis data dalam penelitian ini, maka uji prasyarat yang dilakukan adalah uji normalitas dan uji homogenitas dengan menggunakan SPSS 17.0 dengan angka signifikan yang lebih besar dari 0,05. Selain menggunakan SPSS 17.0 perhitungan uji normalitas juga dilakukan dengan menggunakan Ms. Excel 2010 dengan rumus Chi-Square. Uji homogenitas data juga dilakukan dengan menggunakan Ms. Excel 2010 dengan menggunakan rumus sebagai berikut

$$
F_{\text {hit }}=\frac{{s_{1}}^{2}}{s_{2}{ }^{2}}
$$

Keterangan :

$$
\begin{array}{ll}
\mathrm{s}_{1}{ }^{2} & : \text { varians terbesar } \\
\mathrm{s}_{2}{ }^{2} & \text { : varians terkecil }
\end{array}
$$

\section{Uji Hipotesis}

Secara statistik hipotesis tersebut dapat dirumuskan sebagai berikut:

$$
\begin{aligned}
& \mathrm{H}_{0:}{ }^{\mu_{1}}=\mu_{2} \text { melawan } \mathrm{H}_{1}=\mu_{1}>\mu_{2} \\
& \text { Artinya adalah : } \\
& \mathrm{H}_{0}: \mu_{1}=\mu_{2} \quad \text { : Tidak terdapat hasil belajar yang } \\
& \text { lebih tinggi antara siswa yang } \\
& \text { menggunakan e-learning kelas } \\
& \text { maya dengan siswa tanpa } \\
& \text { menggunakan e-learning pada } \\
& \text { siswa kelas X juruasan perhotelan } \\
& \text { SMK PGRI } 3 \text { Badung } \\
& \mathrm{H}_{1}: \mu_{1}>\mu_{2} \quad \text { : Terdapat hasil belajar yang lebih } \\
& \text { tinggi antara siswa yang belajar } \\
& \text { menggunakan e-learning kelas } \\
& \text { maya dengan siswa tanpa } \\
& \text { menggunakan e-learning pada } \\
& \text { siswa kelas X jurusan perhotelan }
\end{aligned}
$$

ISSN 2252-9063

Kumpulan Artikel Mahasiswa Pendidikan Teknik Informatika

(KARMAPATI)

Volume 8 Nomor 2 Tahun 2019

SMK PGRI 3 Badung

Untuk menguji hipotesis dengan menggunakan uji-t. Uji ini digunakan untuk menguji hasil posttest kelompok eksperimen dan kelompok kontrol. Uji-t untuk sampel yang tidak berkorelasi atau terpisah terdiri dari dua jenis rumus, yaitu separated varians dan polled varians.

Rumus Separated Varians:

$$
t=\frac{\overline{X_{1}}-\overline{X_{2}}}{\sqrt{\frac{s_{1}^{2}}{n_{1}}+\frac{s_{2}{ }^{2}}{n_{2}}}}
$$

Rumus Polled Varians:

$$
t=\frac{\bar{X}_{1}-\bar{X}_{2}}{\sqrt{\frac{\left(n_{1}-1\right) s_{1}{ }^{2}+\left(n_{2}-1\right) s_{2}{ }^{2}}{n_{1}+n_{2}-2}\left(\frac{1}{n_{1}}+\frac{1}{n_{2}}\right)}}
$$

Keterangan :

$\bar{X}_{1} \quad=$ Nilai rata-rata skor kelompok eksperimen

$\bar{X}_{2}=$ Nilai rata-rata skor kelompok kontrol

$n_{1} \quad=$ Banyaknya siswa kelompok eksperimen

$n_{2} \quad=$ Banyaknya siswa kelompok kontrol

$s_{1}{ }^{2} \quad=$ varians kelompok eksperimen

$s_{2}{ }^{2} \quad=$ varians kelompok kontrol

Pedoman penggunaan rumus-rumus t-test (Separated Varian, dan Polled Varian, yaitu sebagai berikut :

1. Bila jumlah siswa $\mathrm{n}_{1}=\mathrm{n}_{2}$, dan varian homogen maka dapat digunakan rumus t-test baik untuk Separated, maupun Polled Varian. Untuk melihat harga t-tabel digunakan $\mathrm{dk}=\mathrm{n}_{1}+\mathrm{n}_{2}-2$

2. Bila $\mathrm{n}_{1} \neq \mathrm{n}_{2}$, varian homogen dapat digunakan rumus ttest dengan Polled Varian. Derajad kebebasan $(\mathrm{dk})=\mathrm{n}_{1}+$ $\mathrm{n}_{2}-2$

3. Bila $\mathrm{n}_{1}=\mathrm{n}_{2}$ varian tidak homogen, dapat digunakan rumus t-test dengan Separated Varian dan Polled Varian. Dengan $\mathrm{dk}=\mathrm{n}_{1}-1$ atau $\mathrm{n}_{2}-1$.

4. Bila $\mathrm{n}_{1} \neq \mathrm{n}_{2}$, varian tidak homogen untuk ini digunakan $\mathrm{t}$ test dengan SeparatedVarian. Harga t sebagai pengganti $\mathrm{t}$-tabel dihitung dari selisih harga t-tabel dengan $\mathrm{dk}\left(\mathrm{n}_{1}-\right.$ 1) dan dk $\left(n_{2}-1\right)$ dibagi dua, dan kemudian ditambahkan dengan harga t yang terkecil.

Untuk mendapatkan hasil yang kebih akurat analisis uji-t dilakukan dengan dua cara, yaitu secara manual dan dengan bantuan program SPSS PC 17.0 for windows. Apabila cara manual untuk menghasilkan interprestasi, maka thitung tersebut harus dikomparasikan dengan $t_{\text {tabel }}$ dengan indikator taraf signifikan 5\% (0,05). Apabila thitung lebih besar daripada $t_{\text {tabel }}\left(t_{\text {hitung }}>t_{\text {tabel }}\right)$, maka terdapat perbedaan yang signifikan 


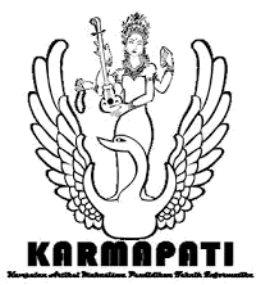

antara kedua variabel atau sampel. Sedangkan apabila thitung lebih kecil dari $t_{\text {tabel }}\left(t_{\text {hitung }}>t_{\text {tabel }}\right)$ maka tidak terdapat hasil belajar yang tinggi antara kedua variabel atau sampel. Angka signifikan antara kedua variabel atau sampel. Angka signifikasi lebih kecil dari 0,05 berarti $\mathrm{H} 0$ ditolak dan artinya terdapat perbedaan variabel bebas antar kelompok menurut sumber.

\section{Teknik Analisis Deskriptif Respon Siswa}

Respon siswa terhadap penggunaan media pembelajaran e-learning kelas maya pata mata pelajaran simulasi dan komunikasi digital. Data yang dikumpulkan dengan menggunakan angket tanggapan siswa. Angket yang digunakan adalah skala Likert dengan pilihan Sering Sekali (SS), Sering (S), Kadang-kadang (KK), Jarang (J), dan Jarang Sekali (JS), sedangkan untuk respon negatif pemberian skor terbalik dengan item positif . Untuk mencari rata-rata atau mean $(\bar{X})$ dapat dilakukan dengan membagi jumlah semua skor $\left(\sum X\right)$ dengan jumlah siswa $(\mathrm{N})$ dengan rumus sebagai berikut

$$
\bar{X}=\frac{\sum X}{N}
$$

Keterangan :

$\bar{X} \quad=$ Skor rata - rata motivasi belajar

$\mathrm{X}=$ skor motivasi belajar dari masing - masing siswa

$\mathrm{N} \quad=$ Banyaknya siswa

Untuk kriteria pemberian skor respon siswa terdapat dalam Tabel 2.

Tabel 2 Kriteria Pemberian Skor Respon Siswa

\begin{tabular}{|c|l|l|}
\hline \multirow{2}{*}{$\begin{array}{c}\text { Analisis } \\
\text { Jawaban }\end{array}$} & \multicolumn{2}{|c|}{ Nilai Item } \\
\cline { 2 - 3 } & Positif & Negatif \\
\hline SS & 5 & 1 \\
\hline S & 4 & 2 \\
\hline KS & 3 & 3 \\
\hline TS & 2 & 4 \\
\hline STS & 1 & 5 \\
\hline
\end{tabular}

Data skor respon siswa kemudian dikategorikan sesuai dengan pedoman pada Tabel 3 berikut.

\begin{tabular}{|c|c|}
\hline \multicolumn{1}{|c|}{ Rentangan Skor } & Kategori \\
\hline $\mathrm{MI}+1,5 \mathrm{SDI} \leq \bar{X}$ & $\begin{array}{c}\text { Sangat } \\
\text { Positif }\end{array}$ \\
\hline $\mathrm{MI}+0,5 \mathrm{SDI} \leq \bar{X}<\mathrm{MI}+$ & Positif \\
$1,5 \mathrm{SDI}$ & \\
\hline $\mathrm{MI}-0,5 \mathrm{SDI} \leq \bar{X}<\mathrm{MI}+$ & Cukup Positif \\
$0,5 \mathrm{SDI}$ & \\
\hline $\mathrm{MI}-1,5 \mathrm{SDI} \leq \bar{X}<\mathrm{MI}-$ & Kurang \\
$0,5 \mathrm{SDI}$ & \\
\hline $\bar{X}<\mathrm{MI}-1,5 \mathrm{SDI}$ & $\begin{array}{c}\text { Sangat } \\
\text { Kurang }\end{array}$ \\
\hline
\end{tabular}

ISSN 2252-9063

Kumpulan Artikel Mahasiswa Pendidikan Teknik Informatika

(KARMAPATI)

Volume 8 Nomor 2 Tahun 2019

\section{HASIL DAN PEMBAHASAN}

Data yang digunakan dalam peneitian ini adalah hasil belajar siswa yang diperoleh dari kelompok eksperimen dan kelompok kontrol. Untuk mengetahui gambaran tentang hasil tes belajar siswa, maka disajikan deskripsi data

Data dari hasil pengukuran hasil post-test yang berjumlah 15 butir soal terhadap 45 siswa kelompok eksperimen menunjukkan bahwa skor tertinggi adalah 67 dan skor terendah 50. Sebelum menyajikan data pada tabel maka ditentukan terlebih dahulu rentangan dan interval data hasil post-test siswa kelompok eksperimen. Menentukan rentangan interval data hasil post-test siswa kelompok eksperimen.

Tabel 4. rentangan interval data hasil post-test siswa kelompok eksperimen.

\begin{tabular}{|l|l|l|l|l|}
\hline No & Interval & $\begin{array}{l}\text { Titik } \\
\text { Tengah } \\
(\mathrm{X})\end{array}$ & $\begin{array}{l}\text { Frekuensi } \\
\text { Absolut (f) }\end{array}$ & $\begin{array}{l}\text { Frekuensi } \\
\text { Komulatif } \\
(\mathrm{F})\end{array}$ \\
\hline 1 & $50-52$ & 51 & 6 & 6 \\
\hline 2 & $53-55$ & 54 & 6 & 12 \\
\hline 3 & $56-58$ & 57 & 7 & 19 \\
\hline 4 & $59-61$ & 60 & 9 & 28 \\
\hline 5 & $62-64$ & 63 & 10 & 38 \\
\hline 6 & $65-67$ & 66 & 7 & 45 \\
\hline \multicolumn{2}{|l|}{ Jumlah } & 45 & \\
\hline
\end{tabular}

Eksperimen

Deskripsi Frekuensi Skor Post-test Kelompok

Tabel 5. Kategori Rentangan Interval Skor Kelompok Eksperimen

\begin{tabular}{|l|l|}
\hline Rentang Skor & Klasifikasi \\
\hline $60 \leq \mathrm{X}<75$ & Sangat Tinggi \\
\hline $50 \leq \mathrm{X}<60$ & Tinggi \\
\hline $40 \leq \mathrm{X}<50$ & Sedang \\
\hline $30 \leq \mathrm{X}<40$ & Rendah \\
\hline $15 \leq \mathrm{X}<30$ & Sangat Rendah \\
\hline
\end{tabular}

Rata-rata skor hasil belajar dengan menggunakan kelas maya berbasis Proyek adalah 59,13 Berada pada interval $50 \leq \mathrm{X}<60$. Berdasarkan tabel di atas, dapat disimpulkan bahwa data hasil belajar siswa yang menggunakan kelas maya berbasis Proyek termasuk pada kategori " Tinggi',

Data dari hasil pengukuran hasil post-test yang berjumlah 15 butir soal terhadap 45 siswa kelompok eksperimen menunjukkan bahwa skor tertinggi adalah 55 dan skor terendah 39. Sebelum menyajikan data pada tabel distribusi frekuensi maka ditentukan terlebih dahulu rentangan dan interval data hasil post-test siswa kelompok kontrol.

Tabel 6. Deskripsi Frekuensi Skor Post-test Kelompok Kontrol

\begin{tabular}{|l|l|l|l|l|}
\hline No & Interval & $\begin{array}{l}\text { Titik } \\
\text { Tengah } \\
(\mathrm{X})\end{array}$ & $\begin{array}{l}\text { Frekuensi } \\
\text { Absolut (f) }\end{array}$ & $\begin{array}{l}\text { Frekuensi } \\
\text { Komulatif } \\
(\mathrm{F})\end{array}$ \\
\hline
\end{tabular}




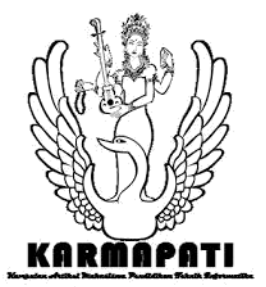

\begin{tabular}{|l|l|l|l|l|}
\hline 1 & $39-41$ & 40 & 8 & 8 \\
\hline 2 & $42-44$ & 43 & 9 & 17 \\
\hline 3 & $45-47$ & 46 & 8 & 25 \\
\hline 4 & $48-50$ & 49 & 7 & 32 \\
\hline 5 & $51-53$ & 52 & 7 & 39 \\
\hline 6 & $54-56$ & 55 & 6 & 45 \\
\hline \multicolumn{2}{|l|}{ Jumlah } & 45 & \\
\hline
\end{tabular}

Tabel 7. Kategori Rentangan Interval Skor Kelompok kontrol

\begin{tabular}{|l|l|}
\hline Rentang Skor & Klasifikasi \\
\hline $60 \leq \mathrm{X}<75$ & Sangat Tinggi \\
\hline $50 \leq \mathrm{X}<60$ & Tinggi \\
\hline $40 \leq \mathrm{X}<50$ & Sedang \\
\hline $30 \leq \mathrm{X}<40$ & Rendah \\
\hline $15 \leq \mathrm{X}<30$ & Sangat Rendah \\
\hline
\end{tabular}

Rata-rata skor hasil belajar siswa yang belajar tanpa menggunakan kelas maya berbasis Proyek adalah 46,78. Berada pada interval $40 \leq X<50$. Berdasarkan tabel di atas, dapat disimpulkan bahwa data hasil belajar siswa yang belajar tanpa menggunakan kelas maya berbasis Proyek pada kategori "Sedang"

Hasil analisis menunjukan bahwa angka signifikan yang dihasilkan secara terpisah lebih besar dari 0,05. Dengan demikian dapat disimpulkan bahwa variabel hasil belajar adalah homogen, sehingga uji hipotesis menggunakan analisis Uji-t. Oleh karena sudah dipenuhi semua uji prasyarat analisis yaitu uji normalitas sebaran data dan uji homognitas varians sehingga uji hipotesis menggunakan $\mathrm{Uji}-\mathrm{t}$

\section{Hasil Respon Siswa}

Data dari hasil respon siswa terhadap penggunaan $E e$ learning kelas maya pada mata pelajaran mata pelajaran simulasi dan komunikasi terhadap 45 siswa kelompok eksperimen. Respon siswa terhadap penggunaan e-learning kelas maya pada mata pelajaran teknik simulasi dan komunikasi yang dikumpulkan dengan kuisioner atau angket tanggapan siswa. Angket yang digunakan dalam skala Likert dengan pilihan Sangat Setuju (SS), Setuju (S), Kurang Setuju (KS), Tidak Setuju (TS), dan Sangat Tidak Setuju (STS). Untuk respon siswa negatif pemberian skor terbalik dengan item positif.

Gambar 1. Histogram Respon Siswa
ISSN 2252-9063

Kumpulan Artikel Mahasiswa Pendidikan Teknik Informatika

(KARMAPATI)

Volume 8 Nomor 2 Tahun 2019

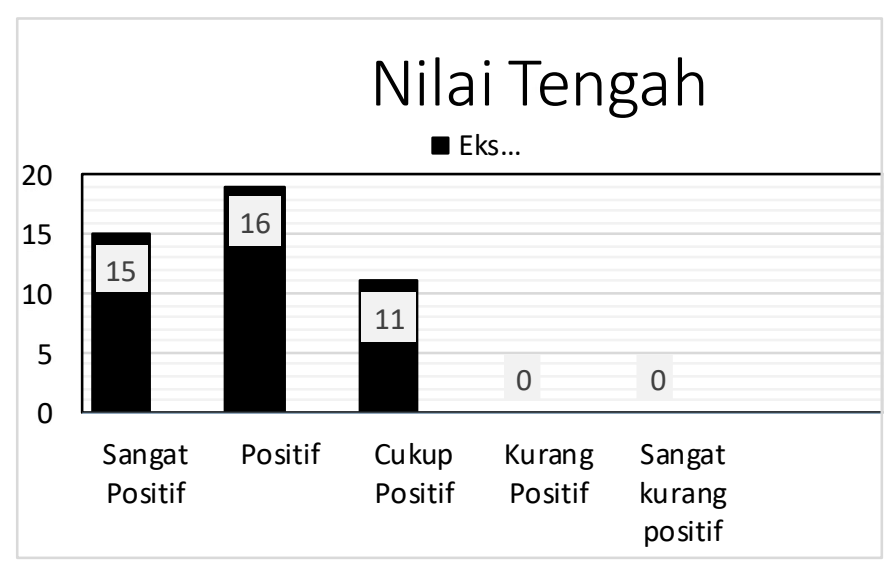

Pada Gambar 1. dapat diketahui bahwa respon siswa terhadap penggunaan e-learning kelas maya terhadap mata pelajaran simulasi dan komunikasi sebanyak 33,33\% berkategori sangat positif, sebanyak $42,22 \%$ berkategori positif, 24,44\% berkategori cukup positif serta tidak ada respon penggunaan e-learning kelas maya yang berkategori kurang positif dan sangat kurang positif. Hasil respon siswa secara lengkap

\section{Pembahasan Hasil Penelitian}

Pada bagian ini dibahasa lebih lanjut mengenai hasil penelitian yang telah diperoleh. Hasil penelitian meliputi analisis deskriptif dan analisis statistic yang mengungkap pengaruh variable bebas terhadap variable terikat. Variabel bebas dalam penelitian ini adalah media pembelajaran elearning kelas maya sedangkan variable terikat dalam penelitian ini adalah hasil belajar Mata Pelajaran Simulasi dan Komunikasi Digital.

Dalam penelitian ini, pemilihan sampel yang digunakan sebagai kelas eksperimen dan kelas kontrol dilakukan uji kesetaraan terlebih dahulu untuk menyakinkan bahwa kelas benar-benar dalam keadaan setara dari segi kemampuan akademisnya. Setara dalam artian pengelompokan siswa ke dalam kelas-kelas tersebut disebar secara merata antara siswa yang memiliki kemampuan tinggi, sedang, dan rendah.

Setelah mendapatkan pasangan kelas yang setara sebanyak dua kelas, selanjutnya dilakukan teknik Simple Random Sampling untuk menentukan kelas yang akan digunakan sebagai sampel. Hasil pengundian didapatkan bahwa kelas XPerhotelan 1 sebagai kelas eksperimen dan XPerhotelan 2 adalah kelas Kontrol. Kelas eksperimen adalah kelompok yang diberi perlakuan yaitu dengan pembelajaran yang menggunakan media pembelajaran e-learning kelas maya, Kelas kontrol adalah kelompok siswa yang belajar dengan menggunakan media power point.

selanjutnya diberikan tes akhir pada kelas eksperimen dan kelas kontrol dengan tujuan untuk mengetahui hasil belajar 


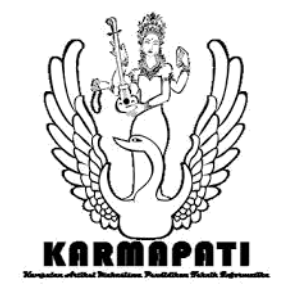

siswa setelah diberi perlakuan. Analisis dari hasil penelitian didapat bahwa rata-rata post test hasil belajar Simulasi dan Komunikasi Digital yang dicapai siswa pada kelompok eksperimen adalah 59,13 sedangkan rata-rata post test hasil belajar Simulasi dan Komunikasi Digital untuk kelompok kontrol sebesar 46,78.

Kedua temuan tersebut menunjukkan bahwa terdapat hasil belajar yang lebih tinggi pada pelajaran Simulasi dan Komunikasi Digital antara siswa yang belajar menggunakan media pembelajaran kelas maya dengan siswa yang belajar menggunakan media pembelajaran power point dengan model secara langsung di SMK PGRI 3 Badung.

Hasil belajar kelas eksperimen yang menggunakan media pembelajaran kelas maya pada Mata Pelajaran Simulasi dan Komunikasi Digital lebih baik, dilihat dari nilai rata-rata skor siswa kelompok eksperimen lebih tinggi dibandingkan kelompok kontrol $(59,13>46,78)$.

Dalam penelitian ini adapun kendala-kendala yang dihadapi peneliti saat menerapkan e-learning adalah ada beberapa siswa tidak memiki jaringan internet sehingga peneliti mengatasinya dengan menyediakan jaringan internet yang dapat digunakan dalam proses pembelajaran berlangsung dan jurusan perhotelan belum dapat menggunakan atau belajar e-learning kelas maya maka dalam penelitian bahwa jurusan perhotelan belum dapat pembelajaran e-learning maka saya di sana akan menerapkan bagaimana cara memakai e-learning tersebut.

Kedua, Guru memiliki kesibukan yang tidak dapat ditinggalkan sehingga tidak jarang pembelajaran dimulai lebih lambat dan dipercepat dari pada waktu yang sudah ditentukan. Solusi yang diberikan terhadap kendala ini adalah, mahasiswa selaku peneliti mengarahkan siswa untuk tetap mempelajari materi yang sudah ada pada e-learning kelas mayas ehinggga pelaksanaan pembelajaran dapat berlangsung dengan baik.

Berdasarkan pertimbangan-pertimbangan teoritik dan operasional, maka implikasi dari penelitian ini jika dilihat dari teori belajar konstruktivisme adalah proses belajar dan pembelajaran dikelas. Siswa harus dapat mengaplikasikan ideide mereka sendiri, siswa harus mengkonstruksikan pengetahuan mereka sendiri sehingga hasil belajar dicapai dengan lebih baik. Berdasarkan hal itu media ajar yang dapat digunakan untuk mencapai hasil belajar dengan lebih baik adalah media pembelajaran e-learning kelas mayapada mata pelajaran simulasi dan komunikasi digital.

\section{SIMPULAN}

ISSN 2252-9063

Kumpulan Artikel Mahasiswa Pendidikan Teknik Informatika

(KARMAPATI)

Volume 8 Nomor 2 Tahun 2019

Berdasarkan hasil penelitian dan pembahasan, dapat dikemukakan beberapa simpulan. Adapun simpulan yang akan dikemukakan dalam penelitian ini adalah sebagai berikut.

1. Berdasarkan hasil penelitian dan pembahasan, diketahui bahwa diperoleh angka sig (2- tailed) = 0,000. Ini berati $\mathrm{p}<0,05$ dapat ditarik kesimpulan bahwa terdapat perbedaan hasil belajar yang signifikan antara siswa yang belajar menggunakan $e$ learning kelas maya dengan siswa yang belajar tanpa menggunakan e-learning kelas maya. Dengan demikian penerapan e-learning kelas maya memberika pengaruh positif terhadap hasil belajar siswa kelas $\mathrm{X}$ jurusan Perhotelan SMK PGRI 3 Badung.

2. Hasil dari analisis respon siswa dari penggunaan $e$ learning kelas maya pada mata pelajaran simulasi dan komunikasi dilihat dari rata-rata skor respon siswa sebesar 74,18 adalah termasuk dalam kategori positif. Berdasarkan hasil penelitian dapat diajukan beberapa saran guna meningkatkan kualitas pembelajaran Simulasi dan Komunikasi Digital

1. Hasil penelitian ini menunjukkan bahwa siswa yang belajar dengan menggunakan e-learning memperoleh hasil belajar yang lebih baik dari pada siswa yang menggunakan media pembelajaran konvensional.

2. Peneliti juga menyarankan kepada peneliti lain yang akan melakukan penelitian sejenis agar bisa mengkondisikan keadaan kelas sebaik mungkin ketika melaksanakan tes akhir (post test).

\section{REFERENSI}

[1]. Agustini,K., Wahyuni,D.S.,(2013). Pengaruh Penggunaan Simulasi Binary Tree Berbasis CAI Terhadap Motivasi dan Hasil Belajar Matematika Diskrit Mahasiswa Jurusan PTI Undiksha. Jurnal Pendidikan Indonesia. ISSN: 2303-255x Hal: 162-172.

[2]. Arikunto, S. (1993). Procedure penelitian Suatu Pendekatan Praktek. Jakarta: PT Rineka Cipta

[3]. Arikunto, S. (2005). Managemen Penelitian. Jakarta: PT. Rineka Cipta.

[4]. Azwar,S.(2012). Reliabilitas dan Validitas. Yogyakarta: Pustaka Pelajar

[5]. Candiasa, I. M. (2010). Statistik Multivariat Disertai Aplikasi SPSS. Singaraja: Unit Penerbit Undiksha.

[6]. Candiasa, I.M. (2011). Pengujian Instrumen Penelitian disertai Aplikasi ITEMAN dan BIGSTEPS. Singaraja: Unit Penerbitan Undiksha. . 
ISSN 2252-9063

Kumpulan Artikel Mahasiswa Pendidikan Teknik Informatika

(KARMAPATI)

KaRmaPaTI

Volume 8 Nomor 2 Tahun 2019

[7]. Nursalam, \& Efendi, F. (2008). Pendidikan dan Keprawatan .Jakarta: Salemba Medika

[8] Prasojo, Lantip Diat dan Riyanto. 2011. Teknologi Informasi Pendidikan. Yogyakarta: Gava Media 